\title{
Introduction: Landscape with Figures
}

THE REPUBLIC OF TEXAS was, in the spring of 1837, a 1 fragile though boisterous infant. Its treasury was empty; indeed the word "treasury" was a presumption. Its national defense was less realistic than it had been during the spring campaign of 1836. Its land policy was largely unformed, its administrative agencies were undefined, and its economy had not yet reached the maturity even of predatoriness. Its population was made up in large measure of young males without the skills needed to build the most primitive community. So disproportionately masculine was the Republic that not until June, 1837, did Congress get around to providing means by which a couple might be married by the statutory officials of the Republic. ${ }^{1}$

Sam Houston, the first constitutional president, lived in a hovel in Columbia until April, 1837, when he removed to another in Houston. ${ }^{2}$ Profane, flamboyant, bombastic, often drunk, nursing his own counsels, and frequently running roughshod over the Constitution and the legislative branch, he dramatized a leadership he did not always provide. Congress, its members given to love of liquor, gambling, and private speculation-which was joined in some with as much ignorance of political science, administrative practice, and economics as of grammar-was as capable of passing on the same day two bills each setting up wholly divergent county governments as the President was of approving both. ${ }^{3}$ The judiciary, 


\section{Introduction: Landscape with Figures}

except for one or two competent district judges and a few conscientious justices of the peace, partook more of the nature of a kangaroo-court system than of machinery designed to execute even a purblind justice. Yet in the best American tradition, there was hope, self-reliance, optimism, and a determination to create Utopia.

Into this milieu came a spectator with pencil poised over notebook, and out of the observations and hearsay he had jotted therein, he distilled an account published under the title "Notes on Texas." These Notes-in twenty-five chapters ${ }^{4}$ -appeared between September, 1838, and April, 1839, inclusive, in a monthly literary magazine, Hesperian, published in Columbus, Ohio. ${ }^{5}$ The author is nowhere identified by name, although in three places he is referred to as a "Citizen of Ohio," and he thrice signed himself $R .{ }^{7}$ No reprinting of the entire work has appeared heretofore, but the first eight chapters were issued as a thirty-five-page pamphlet in 1926 by the Union National Bank of Houston under the misleading title Houston and Galveston in the Years 1837-8.

After the last of "Notes on Texas" had appeared in the Hesperian, the editor of that journal was moved to write:

Justice to the author requires that we should here state that the distance of his residence from our place of publication precluded his examining the proof-sheets of his "Notes," some chapters of which have been marred by typographical errors. It was his intention to have transcribed all the manuscripts, before publishing them; but this he was prevented from doing, by other engagements, and the "Notes" as given to our readers are the first hasty drafts from the original memoranda. These things are mentioned not for the purpose of disarming animadversion, but merely to show the true cause of the marks of haste that are apparent in some of the chapters, and to account for the typographical errors in others. ${ }^{8}$

In this editorial note, it is clearly stated that the work as published was the author's first hasty draft, no doubt, like most first drafts, whether hasty or deliberate, filled with minor inaccuracies if not indeed with major ones. Then, too, the printer, entering enthusiastically into the spirit of the venture, contributed his own share of typographical errors. To further the 


\section{Introduction: Landscape with Figures}

matter, the author's handwriting was occasionally illegible, as evidenced, for example, by the printer's setting up in one place "Prisoners" where the author must obviously have written "Provisions."

As the original printing of the work is readily available to anyone wishing to consult it, I have endeavored in this edition to present the material in what I consider the most readable fashion. In order to distract as little as possible, I have silently expanded initials, modernized spelling, redivided paragraphs, rectified the glaring grammatical errors and all the orthographical errors, adjusted minor errors of fact when they were obvious slips of the pen and might be corrected by altering a word or two, and cleaned up the untidy punctuation. In justice to the author, it must be said that many of the misspellings appear to have been the result of the printer's deficiency, but there are two that are of interest in placing the work in its temporal setting: the author consistently wrote "prairy" and "musketoe." He always tried to spell proper names and foreign words phonetically, but in virtually every case, especially those in French, Spanish, and German, his transliterations missed the mark. The only significant error of this sort, though, was his writing Cibolo as "Seawillow," a common rendering of the time that reminds one of the curiously named stream in Colorado, the Picketwire, which is no more or less than Purgatoire as spelled by a semiliterate frontiersman.

Although the publisher went to the trouble to copyright "Notes on Texas" and to intimate that the author might be induced, with the aid of additional information at his command, to elaborate them into a volume of octavo size, ${ }^{9}$ no separate printing ever fell from the press. By the time serial publication had begun, even though the Notes were regarded as "the most intelligent, accurate, and impartial account of Texas, which has yet been given to the people of the United States," ${ }^{10}$ they were already outmoded. Events had outrun printing. An emigrant of 1839 who followed the advice that he found therein, except such parts as suggested farming as the surest means of obtaining a livelihood and winter clothing as a necessity, would have found himself in a box. 


\section{Introduction: Landscape with Figures}

I regret that I have been unable to identify the author. The New Orleans newspapers of the time did not publish passenger lists of ships clearing that port, as did the El Dorado, on which the author came to Texas. The Telegraph and Texas Register was in the habit of running such lists for entering ships, but at the time the newspaper was published in Columbia, which had no direct communication with Galveston Island, and so took no notice of the El Dorado's arrival. The passenger manifests of the New Orleans customhouse would be the most likely place to seek a lead, but the early records of that office, as it turned out, were sent some years ago to the National Archives in Washington, and the passenger manifest of the El Dorado is not among them.

Though his name is not available, a considerable body of information about the author is revealed in internal evidence. His surname probably began with the letter R. At the time of the publication of his Notes, he was a resident of Ohio, probably of Cincinnati, then a long distance from Columbus. He certainly was a Southerner, as his casual and unquestioning references to slavery indicate. And his prejudices were in the New England post-Calvinistic tradition. He referred to Sunday as "the Sabbath," and he regarded the Pilgrims, a very trying collection of folk at best, as heroes. This conclusion is buttressed by his quotations from John Milton, whom the Puritan mind of the eighteenth and early nineteenth centuries regarded as the greatest English poet, and by his conspicuous neglect to quote Shakespeare a single time, despite his penchant for quoting, though he was familiar with the Shakespearean characters. His southern origin and his theological direction are confirmed in his comments on the first religious service in Houston. He describes Zachariah N. Morrell (1803-83), who delivered the sermon on that occasion, as "the instructor of my youth and the companion of after life." Between 1816, when he was moved to climb into the pulpit, and 1835, when he left for Texas, Morrell preached as a Baptist elder in Pulaski, Tennessee. ${ }^{11}$ The author of the Notes, then, must have lived in Pulaski before moving to Ohio. Since he was a youthful protégé of Morrell, he must have been born 


\section{Introduction: Landscape with Figures}

in the nineteenth century and was, therefore, a young man at the time of his visit to Texas. Whether he was still a Baptist when he wrote, or indeed had ever been a Baptist, would require additional information.

Despite his post-Calvinistic Weltanschauung, he appears to have been attracted to the doctrine of progress and to the Romantic movement, as witnessed by his allusions to improvement and his quotations from George Gordon, Lord Byron. A synthesis of post-Calvinism and Romanticism would indeed have been a difficult feat to bring off, but his numerous and curious references to a personal and purposive Nature suggest a possible alternative. In the United States there was and still is a sect of Baptists known as the Glassites, stemming from the Particular or Calvinistic Baptists of Scotland, who on their native heath combined the Calvinistic doctrine of man with a pantheistic nature doctrine similar to Swedenborg's and in America Calvinistic soteriology with Romantic or Transcendental cosmology and theology. ${ }^{12}$ Our author must have been a conscious Glassite or one who had reached an approximate position by his own devices.

His extended discussion of the law, especially the common law, with which he obviously had professional acquaintance, suggests he may have been an attorney.

Nowhere does he suggest the motivations of his visit to Texas. He may have been moved by curiosity, or he could have been in search of information about the person or the estate of some kinsman or client who had disappeared into the Texas Revolution.

He spent slightly more than six months in Texas. He arrived at Galveston Island on March 22, 1837, and he was aboard the outbound Phoenix on October 5 and 6, when Racer's hurricane struck the coast and completely inundated the island. Since the Phoenix rode out the hurricane in Galveston Bay, it is likely that the boat cleared a few days afterward. Presumably it did not enter New Orleans, for the marine intelligence of newspapers there fails to show its arrival during October.

In his six-month visit to Texas the author went up Galveston 


\section{Introduction: Landscape with Figures}

Bay, San Jacinto River, and Buffalo Bayou to Houston, where he lingered for some weeks, after which he set out for San Antonio. He appears to have retraced his steps in getting back to Galveston Island. Thus he saw nothing of east Texas, the lower Brazos and Colorado valleys, the planting areas on the upper Brazos, and the settlements between San Antonio and the Gulf of Mexico. His visit, restricted as it was to the spring and summer months and to a narrow though lengthy swath through the Republic, provided him with no firsthand information about the autumn and winter seasons or about a vast proportion of the then settled areas in Texas, to say nothing of the unsettled brush country, hill country, trans-Pecos region, staked plains, and cross timbers. Where he discusses these subjects, he is perforce obliged to use secondhand information, deficient at best and misinterpreted at worst. In describing what he saw with his own eyes, he is graphic and informative. In repeating hearsay, he becomes insipid. His generalizations are usually less significant and interesting than his particulars. This is transparent in his comments on persons. Some of his descriptions of individuals are excellent, but his group portraits are out of focus. When he discusses groups of people he engages in what the sociologists call stereotyping.

A man of at least an academy education-revealed in allusions to Homer, Vergil, and various English authors-he goes far afield in the discussion of earthy matters. A product of the old Southwestern frontier, where the fertility of soil was proportionate to its blackness and its ability to grow that timber which had to be laboriously felled to provide clearings in which to plant crops, he judged the potentialities of Texan husbandry by the preconceptions he had brought with him. Although he foresaw to an accurate degree the extent and indeed the nature of the future cattle industry of Texas, he nowhere showed the faintest comprehension of the direction agriculture was to take. On the positive side, though, because of his preconceptions, he failed to indulge in speculations about the exotic crops that some other travelers fancied: indigo, pineapples, white mulberry for silkworms, and prickly pears for cochineal. Indeed, his Texas is entirely devoid of 


\section{Introduction: Landscape with Figures}

cacti. Competent in describing inanimate nature-expanse of earth, sky, and horizon-and suggestive when sketching trees, he was incapable of or uninterested in portraying insects, reptiles, birds, mammals, and small plants. Apparently he was all but unaware of them, except at times when his delineations are overblown and inaccurate. The chameleon is not so brilliantly colored as he suggests, and he overrates the mockingbird's powers of mimicry. Audubon saw more of the fauna and flora in a few hours from the deck of the United States revenue cutter Campbell in Galveston Bay than our author saw in a fortnight's riding across the prairies. His deficient insight is nowhere more apparent than in his discussion of the navigation of Texan streams. While the critical nature and location of Buffalo Bayou ${ }^{13}$ eluded his grasp, he said far too much about floodtime navigation of the Brazos and Colorado.

Even in what appears to have been his own profession, the law, he discerned only chaos and overlooked the plausible union of the common and the civil law that was soon to produce the doctrines of community property and homestead exemption, the blending of law and equity, and the abandonment of special pleading, which have spread not only throughout the United States but, in part, to wherever the English language is spoken. ${ }^{14}$ But, then, he could not have foreseen the rise to brilliance of John Hemphill. ${ }^{15}$

Despite the author's deficiencies, his "Notes on Texas" contain the best description of the Republic during its first year of more or less intact operation as an independent nation that has yet come to light. For this, one must be grateful. 
